\title{
Dimensions of Informal Sector Association Membership: Experiences from Jua Kali Associations in Western Kenya
}

\author{
Anne-Gertraude Juepner \\ PhD student, \\ Institute for Development Studies, University of Nairobi \\ Prof. Dorothy McCormick \\ Retired as a Research Professor, \\ Institute for Development Studies, University of Nairobi \\ Prof. Njuguna Ng'ethe \\ Associate Research Professor, \\ Institute for Development Studies, University of Nairobi
}

\begin{abstract}
This article explores the various dimensions of membership of informal sector entrepreneurs in business associations they ostensibly formed to pursue their needs and strategic interests. It is based on a case study of Jua Kali Associations (JKAs) in Homa Bay Town in Western Kenya using Hirschman's concept of exit, voice and loyalty as the theoretical frame and data generated and analysed through a qualitative research design. The broad spectrum of membership dimensions ranging from active membership, to dormant membership and non-membership are being examined. The analysis points to certain factors that influence decisions of informal sector entrepreneurs to what degree they engage in their associations. The study further shows that there are jua kalis who decided not to join any association in the first place. Only very few jua kalis took the conscious decision to exit their associations (often due to disappointment and frustration) leading to 'open exit'. The study concludes that exit is multifaceted and that this experience merits attention since it contributes to the fact that only a very small number of all informal sector entrepreneurs operating in Homa Bay Town were JKA members utilizing the associations in pursuit of their organized voice.
\end{abstract}

Key words: Jua kali Associations membership, Exit and Voice, Informal Sector, Kenya

\section{INTRODUCTION}

The term 'informal sector' was first coined in 1971 by Keith Hart, who established a dualist model of income opportunities of the African urban labour force consisting of formal or wage employment and informal or self-employment [28]. Subsequent studies have emerged from different standpoints comprising more in-depth and sometimes conflicting perspectives. As a result, there is a general understanding that the original dualistic model of an economy as introduced by Hart is too simplistic and that there is no clear dividing line between the informal and formal sectors $[22,51,54]$. Instead, there are varying degrees of informality in an informality-formality continuum meaning that informal sector entrepreneurs, i.e. the women and men who own and run informal enterprises/businesses, are engaged in various business activities which do not fully comply with all legal requirements applicable to a formal business. For instance, the informal business may lack formal registration with the applicable authority, or its income is not taxed; or it does not provide minimum wages to its workers who might not be protected by existing labour laws. Informal sector entrepreneurs often employ fewer than 
ten workers and, in many cases, they do not employ any worker on a continuous basis, but instead work on their own account [30].

In Kenya, there has been a great debate in government circles as to what activities should be considered informal sector or jua kali activities ${ }^{1}$. The original focus (in line with the government's understanding of industrialization as the preferred path to economic growth and development post-independence) lay on artisans manufacturing goods, such as metalworkers, carpenters as well as dress makers and tailors. Selected service providers such as car mechanics were also included in the early jua kali terminology. There was a clear understanding that people involved in non-manufacturing activities such as trading and hawking were not to be considered jua kalis. Early government interventions reflect this view: For instance, the establishment of the Kenya Industrial Estates (KIE) Limited in 1967 was undertaken with a view to promote indigenous entrepreneurship by financing and developing small scale and micro enterprises. KIE facilitates the development and incubation of micro, small and medium enterprises (MSMEs) across Kenya by establishing industrial parks, providing credit and business development services. It falls under the authority of the Ministry of Industrialization and Enterprise Development [81]. Lately, jua kali activities are cast more widely and are beginning to also include trade and services as well as manufacturing. The inclusion of farming activities in the 2012 Micro and Small Enterprise Act [33] seems to indicate the latest trend in broadening the jua kali definition. However, clarity on this matter continues to be lacking as some current government statistics (such as the 2018 Economic Survey) explicitly exclude small-scale agricultural and pastoral activities; while the latest survey of Kenya's Micro, Small and Medium Enterprises (MSMEs) includes selected agribusinesses [35:11]. The 2016 MSME Survey lists enterprises by economic activity categories which include manufacturing; wholesale and retail trade/repair of motor vehicles and motorcycles; and accommodation and food service activities [35:26].

Different observations about what constitutes the informal sector and its relationship with the formal sector notwithstanding [38-40, 46, 54, 63], it is important to note that the sector is evident and continues to manifest itself in many different parts of the globe. Above all, it remains a key player in the economies of developing countries regarding both wealth and employment creation amid various challenges. In Kenya, for example, jua kali businesses provide livelihoods for most of the population. In 2017, it was estimated that more than 14 million people (out of a total of 16.9 million people employed) were engaged in jua kali activities, accounting for more than 83 per cent of all people employed outside small-scale agriculture and pastoral activities [36:39]. Nearly 75 per cent of all informal sector activity in 2017 was indicated as having been in rural areas providing livelihoods for more than nine million people [36:50].

A review of existing literature shows that ever since the informal sector gained recognition in both scholarly and policy circles, there have been many initiatives ranging from studies to policy interventions to advance the sector with varying outcomes [42, 47, 53, 57, 65]. In Kenya, for instance, jua kali associations (JKAs) have been celebrated by government and donor agencies as the 'voice' of the informal sector in Kenya once they started to emerge in the early 1990s following the first visit of the then President, Daniel Arap Moi, to jua kalis in Kamukunji, Nairobi, in 1985 [37].

\footnotetext{
${ }^{1}$ Jua Kali is a Kiswahili term referring to people who work 'under the hot sun'. Jua kalis in this paper refer to Kenyan informal sector entrepreneurs.
} 
There are different views about the origins of JKAs. According to Macharia [46], most JKAs owe their origin to artisans and traders coming together with the aim of having one voice for advocacy (mainly in response to harassment experienced by jua kalis from local and central government authorities) and to articulate and pursue their own goals as advocated by Chen et al. [18]. Others emphasize the active involvement of the Kenyan Government in the formation process of JKAs: Many JKAs came into existence after a coordinated drive from the Kenya Government to organize jua kalis in anticipation of expected funding from donor agencies such as the World Bank [26, 37, 52]. This line of thought is also evident in recent jua kali related legislation, the 2012 Micro and Small Enterprise Act. The Office of the MSE Registrar was established with the explicit goal, among others, to "enhance the government's capacity to give direction/issue directives to the jua kalis through their groups" [33:21].The latter has led to a distinct politisation of JKAs and potential dependency of JKAs on external support [26]. Some studies have pointed to the strong link between informal sector groups and local political agendas particularly in times of major elections when access to a large group of potential voters is of special interest $[14,15]$.

McCormick et al. [52] emphasize that the formation of JKAs in Kenya was in many cases the result of initiatives "from below" (referring to jua kalis feeling the need for more of a voice) with support and encouragement "from above" (referring to the government encouraging the formation of JKAs). The promise of benefits to be channelled through these associations was seen as "an additional sweetener" [52:8].

Voice in the informal sector is a topic that has been insufficiently discussed and conceptualized in the literature. It is against this background that the study identified and analysed voice employed by informal sector entrepreneurs, i.e. instances in which jua kalis made efforts to change a situation, rather than to remain quiet or to exit. The focus of the study was on the organised jua kali voice embodied in jua kali associations using a case study of Jua Kali Associations in Homa Bay Town in Western Kenya. It addressed the main research question of how collective action in business associations led to advancing the voice of informal sector entrepreneurs.

The use of voice in this article builds on Hirschman's definition of voice as any attempt to change or escape from an objectionable state of affairs [29:30]. It also draws on feminist thought and empowerment theory [8, 27, 31-32, 50, 66, 67, 70]. Kabeer [31] considers an organized voice (reflecting the views of a particular group of people) essential to ensure the representation of a group's needs and interests in policy discourse and the extension of existing rights and entitlements to excluded groups: "Voice refers to the capacity of people to articulate and advance their needs and interests and to influence critical decision-making processes that affect their lives." [31:280]. Overall, voice here refers to political voice (i.e. the ability to express views and interests and to influence policy and decision-making processes) and entails concrete instances of jua kalis taking collective action through their associations employing an 'organized voice to lobby for greater participation in local or national decisionmaking processes that directly affect their lives.

Developing an organised voice calls for people coming together to jointly advance a particular cause [32, 40, 61-62]. Through organised voice, jua kalis act collectively in groups which can take different forms ranging from informal sector associations to informal social groups and networks through which "ordinary people in their everyday struggles make conscious efforts to overcome their predicaments" [40:6]. Informal sector associations are those membershipbased organizations which comprise informal sector workers who have voluntarily joined together for the purpose of pursuing their common interests as economic actors and business 
people [17]. MBOs here are defined as "those in which the members elect their leaders and which operate on democratic principles that hold the elected office bearers accountable to the general membership" [17:3]. While this definition is rather broad, it signifies the distinction from conventional Non-Governmental Organizations which, however well-intentioned or effective, operate as outside entities since they lack a membership base of those they serve.

These business associations can take the form of cooperatives, savings and credit associations, producer groups as well as jua kali associations (JKAs) in the case of this study. They are often registered in some form with the government and are therefore distinguished from informal social groups and networks which often go unrecognized by the state. Since their clientele comprise workers from the informal sector, these business associations are also distinct from the traditional trade unions representing the needs and interests of formal sector workers. Business associations aim to improve the business and economic development of their members through grassroots organizing and collective bargaining with more powerful economic actors whereby the associations are representing a common position or the voice of their membership.

The business associations registered with a particular government office are required to have basic written documents such as a constitution or by-laws that set out rules for joining and leaving the association, election of officers, management of joint assets, minimum numbers of meetings, etc. These rules may differ depending on the nature of the association (Association, SACCO or Self-Help Group).

It is important to recognize that JKA members can play different roles in the pursuit of voice (and collective action) as acknowledged in the literature, ranging from free-riders (i.e. members who enjoy a benefit accruing from a collective effort, but contribute little or nothing to the effort) and conditional co-operators (i.e. members who will contribute more when others contribute more) to altruists (i.e. members who contribute regardless of others' behaviours), as well as various roles mixing these strategies $[12,78]$.

Whereas studies show that collective action and group formation have a long history [17, 44, 52], Olson [60] cautions against the common assumption that a group of people who have a common interest would naturally get together and fight for the common goal: "Indeed unless the number of individuals in a group is quite small, or unless there is coercion or some other special device to make individuals act in their common interest, rational, self-interested individuals will not act to achieve their common or group interests." [60:2].

This point is echoed by De Wit and Berner [21] in the context of studies of the urban poor in India, who caution that mobilizing and organizing people collectively on the basis of horizontal ties and common interests does not appear to be working well in most places. They argue that people "prefer to rely on vertical patronage, such as relatives or intermediaries, to safeguard livelihoods and obtain (individual) access to persons and institutions of value to them" [21:928]. This seems to be especially the case the poorer and more dependent people are. This logic of patronage is based on the experience that investing in collective action is problematic, time-consuming and fraught with free rider problems. In an association for instance, free riding occurs when a member pays no membership fees, but benefits from association representation.

The literature also acknowledges the diverse effects the size of a group can have on the group's resources (and hence, the realization of the group's objectives): On the one hand, members tend to free-ride as the group becomes larger. As group size increases, transaction costs may 
rise; thus, the larger the group, the more difficult to detect and reduce free-riding. On the other hand, small groups often lack necessary resources (e.g. labour, time, funds) that large groups can deploy. When available resources are limited, it is difficult to devote sufficient resources to collective action. Taking advantage of more resources, large groups may enhance enforcement through monitoring and punishment to reduce free-riders and thus improve collective action and resource outcomes [78].

Similarly, in addition to the benefits of organizing as described above, there are acknowledged challenges in organizing the informal workforce. Although many challenges are specific to the sector informal workers are engaged in or the local context, there seem to be some key issues that are similar across all sectors and regions of the world including conceptual challenges regarding who is to be considered an informal worker (in line with the contested concept of the informal sector), the lack of clear counterparts to negotiate with, the fact that many informal workers are poor and vulnerable which sets practical limits (in terms of available time and financial resources) to their capacity to organize, the diversity in their working conditions often makes it hard for informal workers to define a common position or standpoint from which to negotiate better conditions as well as particular governance and leadership challenges where informal workers have traditionally organized in local groups or associations reflecting local power relations and cultural (mostly informal) institutions [5, 13-14, 15, 18, 64, 82]. According to Hirschman [29], members can leave an organization (or customers can stop buying a firm's products) out of frustration or in protest to the organization's declining management in what he terms "the exit option" [29:4]. Hirschman considers the exit option (mainly in opposition to the "messy" voice option) as "neat - one either exits or one does not" [29:15].

Research shows that only a minority of jua kalis belong to jua kali associations [16, 52]. In the case of Homa Bay Town for example, less than 900 out of the estimated total number of about 5,600 jua kali women and men operating their businesses there, were taking part in the organized jua kali voice by being members of the jua kali associations [34]. Certain groups of jua kalis, such as trainees in jua kali businesses and many of those jua kalis interviewed who do not need any permanent workspace to carry out their business (mainly jua kali men engaged in fishing and riding of motorbikes or 'boda-bodas'), were not part of the JKA membership.

This leads to some key questions: Are existing jua kali associations a sign of being effective tools for advancing the voice of informal sector entrepreneurs in Kenya? Or is the fact that most jua kalis are not members of jua kali associations a sign of jua kalis exercising the 'exit option' and forming alternative groupings that they find more suitable in responding to their needs such as other jua kali or welfare groups? Or are jua kalis 'stuck' between exit and voice: unable or not wanting to leave existing jua kali associations but unable to or not interested in actively expressing their voice within the associations leading to a large pool of inactive or dormant members?

The discussion in this paper is organised in five sections beginning with the introduction which provides an overview of the concepts of informal sector, and voice and exit. The second section outlines the methodology used to undertake the study. The third section presents the Jua Kali Associations examined; while the fourth discusses the different dimensions of membership among JKA members. The remainder concludes.

\section{STUDY METHODOLOGY}

This article relies on data generated from members of selected Jua Kali Associations in Homa Bay Town in Western Kenya through a qualitative research design. The town is located along 
the shore of Lake Victoria and has historically been a commercial centre. Homa Bay Town has approximately 41,000 inhabitants representing half of Homa Bay County's total urban population [34:13]. The town was chosen for this study due to two reasons. One, it represents small towns in Kenya which have been marginalised in the study of the informal sector. Most of the studies conducted focus on major towns/cities. Focusing on the category of small towns is instrumental in better understanding changing or emerging dynamics within the informal sector with respect to labour migration patterns and employment opportunities $[1,45,58]$. Two, the researcher was familiar with the Homa Bay jua kali environment - a factor which was important in negotiating access to jua kali actors in addition to overcoming field research related challenges.

Overall, the study relied on a case study approach grounded in critical realism and feminist epistemologies. Whereas the former identifies the necessity for human emancipation, presupposing a conception of what it is to be human [10-11], the latter emphasises emancipatory aims from oppressive power relations especially between men and women [4, 19, 27, 59].

The following assumptions underlie the feminist approach to this research. One, there is no objective and value-free research method. Two, there is need for a world which allows for and propagates social change aimed at human emancipation which speaks positively to the notion of voice as the overarching concept in this study.

The case study approach was chosen to generate detailed insight into the complex reality of a local, formally organised jua kali scene. Case studies are known for their ability to provide nuanced, empirically rich, holistic accounts of specific social phenomena $[49,69,75,79,80]$.

Since the study relied on the experiences of jua kali entrepreneurs, their opinion and understandings, perception and (inter)actions, the study employed face to face in-depth interviews in order to generate qualitative data to address the specific issues under examination. Interviewing was conducted in a context-bound and participatory manner [73]. The process was participatory in that jua kalis were encouraged to provide their analysis throughout the process of data generation. Other complementary techniques of data generation employed in the study were direct observation and analysis of secondary data (mainly from documents).

Research participants were selected through purposive sampling to ensure that the desired information is generated from those who have the adequate knowledge on the subject matter [56]. The process paid particular attention to marginalised members of this sector to contribute to an inclusive research process. In total, 100 individual and 5 group interviews were conducted. As highlighted by Morse et al. [56], both saturation and replication were observed in ensuring sampling adequacy in this study.

Analysis of interview data included data reduction, data display, conclusion drawing and verification [55:21]. Overall, the following stages were critical in the data analysis process: One, initial review of interview data which mainly entailed identification of response categories employing content analysis $[48,68]$. Two, sorting of responses into categories using Word tables or 'grids' to identify particular themes [41, 72]. Three, analysis of discursive dimensions which mainly entailed analysis of experience production including the contextual analysis of underlying power relations which shape those experiences recognising the "situated nature of people's accounts" to avoid "naive interview studies in qualitative research" [68:199]. Since experience is voiced through language, the process equally required paying attention to the language used by jua kalis in the interviews to recognize specific terms used by 
the jua kalis and "wanting" language upon which to construct analysis [20:103] as well as consideration of the underlying social processes which would favour the use of such terms and not others.

Qualitative data was presented in the best way possible such as choosing figures to illustrate different themes generated and text boxes to highlight experiences or stories; tables to present selected quantitative information as evidence for the number of interview responses recorded under particular themes and categories [48], and selected quotes from respondents to illustrate identified narrative themes.

Data from direct observation and secondary sources was instrumental in setting the scene for the interview analysis besides providing a framework of reference for the personal accounts of the jua kalis interviewed.

Lastly, the following strategies were employed to verify data generated during the study. One, carrying out of "member checks", i.e. taking data generated from research participants and the initial interpretation of this data back to them to check if interpretations are plausible and "ring true" [43]. Two, conducting peer debriefings that is, exposing oneself to peers "in a manner paralleling an analytical session for the purpose of exploring aspects that might otherwise remain only implicit within the inquirers mind" [43:308].

\section{JUA KALI ASSOCIATIONS EXAMINED}

The focus of the study was the following five JKAs: 1) the Asego Homa Bay Town JKA, 2) the Homa Bay Industrial Self-Help Youth Group, 3) the Asego Homa Bay Jua Kali Savings and Credit Cooperative Society, 4) the Homa Bay Women Entrepreneurs Savings and Credit Cooperative Society, and 5) the Homa Bay Boda Boda Association. These JKAs were selected based on criteria aimed at capturing the majority of registered jua kali women and men in Homa Bay Town from the broadest variety of occupations and socio-economic backgrounds as possible and ensuring a degree of diversity among the JKAs in terms of foci in service provision for their members (with the Savings and Credit Cooperatives or SACCOs focusing specifically on providing loans and credit to their members), and their registration and management arrangements (with particular processes and financial regulations applicable to the SACCOs).

Table 1 provides a summary of the JKAs investigated in the study indicating when they were registered, with what government entity and how many jua kalis are estimated to be their members. 
Table 1: Selected Jua Kali Associations (JKAs): Age, Registration and Size

\begin{tabular}{|c|c|c|c|}
\hline Name of JKA & $\begin{array}{c}\text { Year of } \\
\text { Regis-tration }\end{array}$ & $\begin{array}{l}\text { Government entity } \\
\text { registered with }\end{array}$ & Estimated membership \\
\hline $\begin{array}{l}\text { Asego Homa Bay Town JKA } \\
\text { (AJKA) }\end{array}$ & 2007 & Attorney General & $\begin{array}{l}188 \text { jua kali artisans of various } \\
\text { trades ( } 146 \text { men and } 42 \\
\text { women) [3] }\end{array}$ \\
\hline $\begin{array}{l}\text { Homa Bay Industrial Self- Help } \\
\text { Youth Group (IJKA) }\end{array}$ & 2007 & $\begin{array}{l}\text { Ministry of Gender, } \\
\text { Sports, Culture and } \\
\text { Social Services, } \\
\text { Department of Social } \\
\text { Services }\end{array}$ & $\begin{array}{l}\text { Approx. } 10 \text { jua kali artisans (all } \\
\text { men) located at the Kenya } \\
\text { Industrial Estates (KIE) } \\
\text { compound, Homa Bay Town }{ }^{2}\end{array}$ \\
\hline $\begin{array}{l}\text { Asego Homa Bay Jua Kali } \\
\text { Savings and Credit Cooperative } \\
\text { Society (ASACCO) }\end{array}$ & 2009 & $\begin{array}{l}\text { Commissioner for } \\
\text { Cooperative } \\
\text { Development }\end{array}$ & $\begin{array}{l}223 \text { men and women jua kali } \\
\text { artisans of various trades as } \\
\text { well as traders [7] }\end{array}$ \\
\hline $\begin{array}{l}\text { Homa Bay Women } \\
\text { Entrepreneurs Savings and } \\
\text { Credit Cooperative Society } \\
\text { (WSACCO) }\end{array}$ & 2009 & $\begin{array}{l}\text { Commissioner for } \\
\text { Cooperative } \\
\text { Development }\end{array}$ & $\begin{array}{l}300 \text { women jua kalis of various } \\
\text { trades, predominantly traders } \\
{[73]}\end{array}$ \\
\hline $\begin{array}{l}\text { New Dawn Motor Cycle Youth } \\
\text { Group (BBA) }\end{array}$ & May 2012 & $\begin{array}{l}\text { Ministry of Gender, } \\
\text { Youth, Sports, Culture } \\
\text { and Social Services, } \\
\text { Dep. of Social Services }\end{array}$ & $\begin{array}{l}127 \text { boda-boda operators (all } \\
\text { men) located } \\
\text { within Homa Bay Town }{ }^{3}\end{array}$ \\
\hline \multicolumn{3}{|c|}{ Total estimated JKA membership } & 848 people \\
\hline
\end{tabular}

Source: Field work data (June 2012)

At the time of the field work in June 2012, the Homa Bay Town jua kali scene also comprised various defunct or inactive jua kali groupings such as the previous Homa Bay Cooperative Society and small trade- or location-based jua kali groups. In addition, there were other organizations providing support to jua kalis even though the focus of their support was not only directed at jua kali men and women including the Kenya Women Finance Trust, Commercial Banks and some Non-Governmental Organizations.

However, the selected five JKAs can be assumed to capture most active jua kali group members in Homa Bay Town as of June 2012. They are described in more detail below.

\section{The Asego Homa Bay Town Jua Kali Association}

The Asego Homa Bay Town JKA (AJKA) developed out of the Homa Bay Jua Kali Association. The latter was registered in 1996 with the Attorney General's Office and mostly comprised jua kali artisans engaged in carpentry and joinery works. AJKA was formed with the objective of bringing together under one umbrella Homa Bay town jua kalis in an effort to secure land allocated by the then Municipal Council of Homa Bay dedicated to jua kali development. Members of smaller, trade- or location-specific jua kali groupings (including the Homa Bay Industrial Self-Help Youth Group) came together under the AJKA umbrella. In June 2012, the AJKA was estimated to comprise 188 jua kalis from various trades and professions [3]. This broad membership as well as the composition of the AJKA Executive Committee reflects this 'merger'. Following its registration in 2007, AJKA was allocated a parcel of land by the Homa Bay Municipality located on the main road on the shores of Lake Victoria 4 .

\footnotetext{
${ }^{2}$ Source: Discussions with IJKA officials and members, Homa Bay (June 2012). ${ }^{3}$ Source: Discussions with BBA officials and members, Homa Bay (June 2012).

3 Source: Discussions with BBA officials and members, Homa Bay (June 2012).

4 Source: Observations and discussions with AJKA officials and members, Homa Bay, June 2012.
} 


\section{The Homa Bay Industrial Self-Help Youth Group}

The Homa Bay Industrial Self-Help Youth Group (IJKA) is much smaller in size than the AJKA: group membership comprises about ten jua kali men who are engaged in metalwork, welding and/or carpentry operating out of solidly built workshops at the KIE compound in Homa Bay. IJKA is closely associated with the activities and services provided by the KIE in Homa Bay. IJKA previously existed under the same name, registered in the mid-90s as Self-Help Group under the former Ministry of Social Development. At that time, it seemed to have been dominated by the generation of the 'fathers' of the current members; it fell dormant after the closure of the KIE Homa Bay Branch Office in the late 1990s. IJKA was re-constituted in 2007 under the leadership of the 'sons' of the original IJKA members. New officials were said to have been elected in 2007.

\section{The Asego Homa Bay Jua Kali Savings and Credit Cooperative Society}

The establishment of the Asego Homa Bay Jua Kali Savings and Credit Cooperative Society (ASACCO) was initiated by the AJKA to provide loans and credit to its members. ASACCO was registered as a separate entity by AJKA officials under the former Ministry of Cooperative Development in April 2009. Management of the ASACCO was then handed over to the newly elected ASACCO officials. There continues to be a close link between the AJKA and the ASACCO: AJKA members tend to be part of the ASACCO and vice versa. ASACCO members are drawn from various trades and include jua kali artisans as well as traders and service providers. Members consist of women and men. ASACCO operates a small office next to the Assistant Chief's office behind the Municipal Market in Homa Bay Town ${ }^{5}$. Share deposits of the ASACCO stood at Kshs. 4.5 million in June 2012; an equal amount was indicated as having been lent to members since 2009 [7].

\section{The Homa Bay Women Entrepreneurs Savings \& Credit Cooperative Society}

The Homa Bay Women Entrepreneurs Savings and Credit Cooperative Society (WSACCO) was presenting itself as a new force in the Homa Bay jua kali scene with about 300 women members. It originated out of efforts undertaken by small scale jua kali women traders in Homa Bay Town who knew each other well. These efforts started in 2006; the original idea then was to come up with a merry-go-round-scheme to mobilize funds to address individual needs. This idea grew into the current SACCO. The WSACCO had to overcome opposition from women who had had negative experiences with previous/other SACCOs as well as suspicions from their husbands/other men towards this women-led initiative. The SACCO capitalized on the negative experiences of women of the area also with other lending institutions, especially the Kenya Women Finance Trust which resulted in several women losing their household and other items to KWFT when they defaulted on loan repayments even for a single month. Like the ASACCO, the WSACCO was registered under the former Ministry of Cooperative Development in 2009. The WSACCO operates an office at the garage road in Homa Bay Town and employs two male field officers for collection of loan repayments and contributions. WSACCO members are mainly small-scale traders in various commodities and service providers. Members consist of women only6. In June 2012, the WSACCO savings base stood at Kshs. 5.1 million; a total amount of Kshs. 4.5 million was indicated as having been lent out to about 200 members since 2009 [77:2-4].

\section{The Homa Bay Boda Boda Association}

Like many other small rural towns, Homa Bay Town has recently witnessed the rise of motor bikes imported from India and China. Starting in 2003, when the Kenyan economy purposely

\footnotetext{
${ }^{5}$ Source: Observations and discussions with ASACCO officials and members, Homa Bay, June 2012.

6 Source: Observations and discussions with WSACCO officials and members, Homa Bay, June 2012.
} 
opened itself to the East, these motor bike taxis (or 'boda- bodas') have become a much-valued transport option for many Kenyans since they are cheaper than the common buses and minivans, and able to navigate poorly maintained roads in the rural areas. They are also often much less safe to travel with since only very few bike operators use helmets themselves or offer this crucial protective gear to their passengers. In June 2012, the boda-boda population of Homa Bay Town was estimated to have reached 2,000 bikes. The boda-boda operators, mainly young men in pursuit of more long-term job opportunities, were certainly a new force to reckon in the local jua kali scene. Aggregated based on their parking location within the town, they had started to form groups to lobby for their interests: provision of adequate security to let them operate throughout the day and night being among the top priorities. The 'New Dawn Motor Cycle Youth Group', comprising 127 bike operators located within the town centre, had just been established as a Boda Boda Association (BBA) and was registered by the former Ministry of Gender, Youth, Sports, Culture and Social Services in May $2012^{7}$.

All five JKAs described above have explicitly stated objectives which are expressed in their respective written constitutions or by-laws $[2,6,9,76]$. For most of the JKAs, objectives seem to have been arrived at in consultation with their members and under the close guidance of the government officials responsible for the respective jua kali segment. JKA documents reviewed indicated that objectives were confirmed by members in related JKA meetings. However, to determine the extent of consultations and discussions having taken place with JKA members in the original drafting/formulation of these objectives is rather difficult and there is therefore the risk that stated objectives might reflect the views of JKA officials rather than JKA members, particularly in cases where the JKA membership is rather diverse and, consequently, interests of members cover a broad array of issues.

All five JKAs are clear on wanting to achieve social and economic benefits for their members; while only one JKA, the Asego Homa Bay Town JKA, explicitly states political objectives. While the social and economic objectives seem to be concerned with addressing some of the most immediate individual priorities of the jua kalis, the political objectives suggest a more strategic voice dimension implying a more systematic and long-term engagement with relevant stakeholders and centres of power aimed at the "protection and representation of the interests of members" [2]. Jua kalis' organized voice therefore seems to increase in its strategic and political dimension as JKA objectives move from providing social protection benefits to tackling economic interests to achieving political goals. However, organizations' strategies are not static and can become more political even if an organization started out with primarily economic development objectives [15].

All JKAs set out membership criteria in their constitutions ${ }^{8}$. Common JKA membership criteria include references to age (minimum age to join any JKA is 18 years), business occupation (artisans, traders or motorcycle riders), business location (Homa Bay County/District) and fees/contributions to be paid upon entry into the JKA as well as regularly during the JKA membership. It is interesting to note that all JKAs seem to have an open membership policy except for the BBA which restricts the number of its members to 80 people $[2,6,9,76]$.

\footnotetext{
${ }^{7}$ Source: Observations and discussions with BBA officials and members, Homa Bay, June 2012.

${ }^{8}$ However, during the field work, I was unable to obtain a copy of the IJKA constitution despite several attempts to do so since their seemed to have been a persistent sense of uneasiness from IJKA officials to share this document (perhaps due to the recent change in the JKA leadership). I therefore decided to not further pursue this matter and consequently, no detailed information is available concerning the IJKA. Information concerning the BBA here is based on a review of their draft constitution since the BBA was in the process of fully establishing itself following its registration prior to the field work conducted in June 2012.
} 
The JKAs also explicitly set out rules for resigning from JKA membership as well as for expelling members for misconduct. While in the case of the two SACCOs, the BBA and IJKA, amounts saved by the JKA member would be refunded to the member (or assigned nominees in the case of his/her death), the AJKA clearly stipulates that there would be no refunds of contributions/entry fee in case of a member resigning from the JKA membership or being expelled. This point is worth noting since it might influence the extent of dormant membership in these JKAs $[2,6,9,76]$.

\section{DIMENSIONS OF ASSOCIATION MEMBERSHIP}

Discussions with JKA members and other informants revealed that, far from being homogeneous, participation of jua kalis in their associations varied considerably. There are different dimensions of JKA membership ranging from an active JKA membership where jua kalis fully engage in the organized jua kali voice, to inactive or dormant JKA membership where jua kalis are somewhat 'stuck' between voice and exit, to non-membership where jua kalis have either left their associations or decided not to join any JKA in the first place.

\section{Active Membership Utilizing Voice}

For those jua kalis who were members of the JKAs, the objectives of the JKAs investigated mirrored the individual needs and aspirations of their members well by pursuing the organized jua kali voice through focusing on achieving economic benefits and social protection for their members. A great number of the jua kalis interviewed stated that they joined the JKAs because they "believe in collective strength" and "to realize their aspirations" as their main motivation. When considering in more detail as to why jua kalis joined a particular, and not just any, JKA it became apparent that local context (including the particular business location, people knowing and trusting the respective JKA officials as well as jua kalis following the advice of trusted fellow jua kalis) greatly mattered and deeply influenced business decisions and business-related choices. This finding supports the observation that there is a close relationship between social relations and associations in the jua kali sector [38].

JKA members in Homa Bay predominantly exercised voice to articulate their practical needs and strategic interests which varied among members depending on their social characteristics (most notably gender, age and ethnicity), business backgrounds and socio-economic status leading to different voice issues being prioritized. Variations in needs and priorities notwithstanding, voice among JKA members was mainly triggered whenever there was a concrete threat concerning their immediate needs and interests.

The study's findings also reveal that jua kalis use different avenues in pursuit of voice: Many of the jua kalis interviewed were members of one or more business associations (most commonly a JKA and a Savings and Credit Cooperative Society, SACCO) and other social groupings (including clan- and church-based groups, self-help groups etc. Widow-support and Merry-goround groups were particularly popular with the jua kali women and widows interviewed) at the same time.

\section{Dormant Membership}

In addition to active JKA membership on the one hand, and formal exit from a JKA on the other hand, there is a third scenario to be considered in the context of the JKA membership: inactive or dormant members who are neither fully participating in the pursuit of JKA voice issues nor have they formally withdrawn their JKA membership resulting in them being 'stuck' between exit and voice. 
The case of Philip ${ }^{9}$ illustrates this particular situation: Philip is engaged in the repair of motorbikes or boda-bodas in Homa Bay Town. He works from under a tree at the KIE premises and pays his friend, a fellow jua kali who owns a permanent workshop there, a small fee for keeping his equipment and spare parts in a safe place. Philip has been a jua kali in this profession for a long time and as such had also joined the IJKA. But as promised or expected benefits were not forthcoming, he decided to withdraw from the association; at the time of the interview, he no longer considered himself a JKA member:

"You know, they told us they wanted to bring us money, but we don't know where those monies are ... that is the reason why I decided to leave ..."

Most of the jua kalis working from the KIE premises are members of the IJKA. Exiting the IJKA while maintaining his workspace at the KIE premises, could have posed certain challenges to Philip in terms of keeping his good working relationships with fellow jua kalis there but he does not seem to be concerned:

"I decided to leave this place peacefully because ... I just left it that way, hm ... We are just talking as we left ... there are no stories ... I just left but I have not asked them to refund me ..."

"Leaving" the JKA in Philip's account is a rather loose term and seems to refer more to a personal withdrawal from active participation in IJKA activities (particularly the regular payment of contributions to be saved by the IJKA on behalf of its members) rather than a formal withdrawal from the organization according to Hirschman [29] - in which case both parties would have to take more formal action. Philip would have to more openly and decisively cut ties with the JKA and formalize his withdrawal (at the cost of potential future benefits); while, at the same time, the JKA would have to refund Philip previously made payments/ savings. This does not seem to be in the immediate best interest of either party, and Philip, therefore, seems to have become part of the dormant IJKA membership being 'stuck' between exit and voice.

In the meantime, Philip is pursuing alternative options in support of his personal and business needs:

"I have another group where I come from ... if anything happens, we pay some money, combine resources for funerals and such ... In fact, they can also help me with my business if you request them ... but I have not yet asked them ..."

He also keeps an open mind about joining alternative JKAs and possibly re-joining the IJKA in case it does prove successful in future - without his inputs or engagement at present:

"Yes, my plan is to join other JKAs, any group ... I can even go back to the IJKA if they asked me ..."

This practice employed by Philip can also be considered as 'open exit' where he is more interested in maintaining good relations and staying "peacefully" with JKA members than having his JKA related payments refunded. By avoiding formal withdrawal of his JKA membership, he keeps a door open to return to the IJKA and to reap possible IJKA benefits in the future. Philip's case is an important illustration of the fact that the actions of informal sector entrepreneurs do not seem to reflect decisions as "neat" as Hirschman originally suggested [29:15].

${ }^{9}$ Fictitious name. 
Dormancy (or the lack of activity) seems to occur not only because of loyalty to the respective JKAs as described by Hirschman [29] but might also be an expression of conscious risk avoidance strategies employed by jua kalis $[31,74]$. They therefore represent a unique category that merits further theoretical attention and analysis. Dormant members very often function as a potential breaking block on collective action and have been recognized as problematic in the context of 'free-riding'. A recent paper on Board Leadership however cautioned that before giving up on dormant members it is worthwhile to understand what brought them to that point [23]. It cites lack of motivation from members to participate, leaders wanting to retain control, members not knowing what to do, and personal considerations making participation difficult, as possible root causes for the demonstrated lack of activity which can be countered by appropriate management action.

\section{Non-Membership}

Non-membership can occur either when JKA members exit their associations as per their respective constitutions or by-laws or when jua kalis decide not to join any JKA in the first place.

Discussions with JKA members and other actors confirm that exit is multifaceted and the explanation of why jua kalis exit their JKAs is rather complex: Part of the explanation seems to lie in the inapplicability of the objectives of some of the JKAs examined. Those jua kalis who, due to the nature of their business, do not need any permanent workspace (including most prominently fishermen and boda-boda riders) were not keen on joining a JKA that has among its main objectives the securing of jua kali workspaces. However, jua kalis may still decide to join a JKA that has a different focus, e.g. the SACCOs for the provision of savings and credit facilities. Another possible reason for choosing exit instead of voice by this particular group of jua kalis is the fact that their professions have previously been (and still are) not fully embraced as part of the jua kali sector as advocated by the respective Kenya government offices [35]. In addition, the study generated evidence that jua kalis from the 'classic' jua kali sector (men engaged in typical jua kali professions such as boda-boda repairs and carpentry) decided to leave the JKA often due to disappointment in the association.

There are also jua kalis who opted not to join any JKA in the first place due to previous bad experiences with similar groups. The case of Mark ${ }^{10}$ illustrates this scenario: Mark is a young carpenter who operates his business from a makeshift workshop at the 'carpentry lane' in Homa Bay Town. Mark is still recovering from a bad experience he encountered with a previous group: prior to setting up his business in Homa Bay, he was a member of a small-scale jua kali savings scheme in another town where he contributed $200 \mathrm{Kshs}$ every week. When he was ready to apply for a loan from the group, he went to their respective branch office but did not find any office or any person responsible. He lost 35,000 Kshs this way - which is a lot of money for a young jua kali trying to establish a business. Based on this traumatizing experience, Mark decided not to entrust anybody else with his money ever again - including the jua kali associations of Homa Bay Town whose members "really tried" to convince him to join them. Instead, he is pursuing an alternative investment strategy: He invests in rearing animals such as goats and cows since "they give birth". Mark is convinced that this strategy will earn him better returns on his money compared to the proposed JKA saving schemes.

10 Fictitious name. 


\section{CONCLUSION}

This article sought to examine the different dimensions of membership of informal sector entrepreneurs in business associations they ostensibly established in pursuit of their needs and interests as economic actors. Specific issues discussed include the broad spectrum of membership dimensions ranging from active JKA membership where jua kalis fully engage in the organized jua kali voice, to inactive or dormant JKA membership where jua kalis are somewhat 'stuck' between voice and exit, to non-membership where jua kalis have either left their associations or decided not to join any association in the first place.

The following are the key study findings. One, only some of the informal sector entrepreneurs examined utilize business associations as a vehicle in pursuit of their organized voice. However, for those informal sector entrepreneurs who are business association members, the associations work well. In addition, the study overserved the same entrepreneurs engaging in multiple association membership at the same time. Two, there is a broad spectrum of how informal sector entrepreneurs engage in their associations which goes beyond the voice or exit options as originally described by Hirschman [29]. Three, dormant membership or a scenario where entrepreneurs do not formally exit their association but engage in 'open exit' can be interpreted as a feasible option in an environment where good social relations among informal sector colleagues are crucial. Four, exit rarely results in formal membership withdrawal and also includes informal sector entrepreneurs who opt for not joining any business associations in the first place - often due to previous bad experiences with similar groups.

These findings point at some important implications for policy development and review of current practice. For example, based on the study's findings on jua kalis' exit from business associations, government offices responsible for jua kali development and interested in strengthening the organized jua kali voice, might want to consider a stronger campaign to advocate for a broader jua kali concept comprising all self-employed women and men or micro entrepreneurs regardless of the nature of their business activities (i.e. including traditional activities such as fishing as well as new services such as the boda-boda riders). This might result in a more pro-active and expanded JKA membership base in future due to a change in the attitude of people who do not (yet) perceive themselves as part of the jua kali.

Dormant membership or 'open exit' is recognized by all JKAs as an issue of concern to JKAs collective actions. While all four established JKAs (with the exception of the BBA) aim at a membership base that is as large as possible, this strategy is bound to be problematic as it resonates with the discussion of free riding and the diverse effects the size of a group can have on its resources and the realization of its objectives calling for particular action on the side of the JKA leadership.

These findings lead to the conclusion that exit is multifaceted and that this experience calls for further investigation to better understand and possibly address the factors that prevent informal sector entrepreneurs from more effectively utilizing business associations in pursuit of their organized voice. There is evidence that JKA members (and officials) interviewed recognize that the JKAs must overcome certain, mainly JKA-internal, challenges to make the JKAs more efficient in their operations. And they are willing to work on it by employing voice internally to improve the organized jua kali voice and to reduce the risk of experiencing dormant or exiting members: they are ready to undertake at least one action as individuals to 
help improve the situation in their JKA such as becoming more "active members/officials", "educating others about JKA benefits" and "criticize more vocally" as JKA members ${ }^{11 .}$

Finally, the findings also confirm that economic action is deeply grounded in social relations and dominant culture $[24,25,38]$. While the particular social norms and dominant culture may vary depending on the specific geographical location, the notion that attention to local context in which informal sector entrepreneurs operate greatly matters when examining their voice, will remain relevant and has to be taken into account when undertaking related research, developing policy guidance and reviewing related practice.

\section{References}

African Development Bank. [2012]. Urbanization in Africa. Retrieved from http://www.afdb.org/en/blogs/afdbchampioning-inclusive-growth-across-africa/post/urbanization-in-africa-10143/.

AJKA. [2007]. Constitution and Rules of the Jua Kali Association. Homa Bay, Kenya: Asego Homa Bay Town Jua Kali Association.

AJKA. [2012]. Membership records, June 2012. Homa Bay, Kenya: Asego Homa Bay Town Jua Kali Association. Alcoff, L. \& Potter, E. (Eds.) [1993]. Feminist Epistemologies. London, England: Routledge.

Andrae, G. \& Beckman, B. [2011]. Trade unions, tailors, and civil society. Labour, Capital and Society, 44[1], 18-42.

ASACCO. [2009]. By-laws of ASACCO. Homa Bay, Kenya: Asego Homa Bay Jua Kali Savings and Credit Cooperative Society.

ASACCO. [2012]. Minutes of the 3rd Annual General Meeting held in Homa Bay Town on 26 April 2012. Homa Bay, Kenya: Asego Homa Bay Jua Kali Savings and Credit Cooperative Society.

Batliwala, S. [1994]. The Meaning of women's empowerment: New concepts from action. In G. Sen, A. Germain \& L. C. Chen (Eds), Population policies reconsidered. Health, empowerment and rights [pp. 127-138]. Cambridge, Massachusetts, USA: Harvard University Press.

BBA. [2012]. Constitution. Homa Bay, Kenya: New Dawn Motorcycle Youth Group.

Bhaskar, R. [1975]. A Realist Theory of Science. Leeds, England: Leeds Books Ltd.

Bhaskar, R. [1980]. Scientific explanation and human emancipation. Radical Philosophy, 26, 16-28.

Black, J. (Ed.) [2003]. Oxford Dictionary of Economics (2nd ed.). Oxford, England: Oxford University Press.

Bonner, C. \& Spooner, D. [2011]. Organizing labour in the informal economy: Institutional forms \& relationships. Labour, Capital and Society, 44(1). Retrieved from

http://www.globallabour.info/en/2012/05/organizing_labour_in_the_infor.html.

Bonner, C. \& Spooner, D. (Eds.) [2012]. The only school we have. Learning from organizing experiences across the informal economy. Retrieved from http://www.wiego.org/sites/default/files/resources/files/Bonner_Spooner_The_Only_School_We_Have.pdf.

Carre, F. [2013]. Defining and categorizing organizations of informal workers in developing and developed Countries [WIEGO Organizing Brief No. 8]. Retrieved from

http://www.wiego.org/sites/wiego.org/files/publications/files/Carre-Informal-Worker-Organizations-WIEGOOB8.pdf.

Central Bureau of Statistics (CBS), International Center for Economic Growth (ICEG), and K-Rep Holdings Ltd. (1999). National micro and small enterprise baseline survey. Nairobi, Kenya.

Chen, M. A., Jhabvala, R., Kanbur, R. \& Richards, C. [2006]. Membership based organizations of the poor: Concepts, experience and policy. Retrieved from http://www.arts.cornell.edu/poverty/kanbur/MBOPVolumeOverview.pdf.

Chen, M. A., Vanek, J., Lund, F., Heintz, J., Jhabvala, R. \& Bonner, C. [2005]. Progress of the world's women 2005: Women, work and poverty. New York, USA: UNIFEM.

Collins, P. H. [1991]. Black feminist thought. Knowledge, consciousness, and the politics of empowerment. London, England: Routledge.

11 Source: Discussions with JKA officials and members, Homa Bay, June 2012. 
Devault, M. L. [1990]. Talking and listening from women's standpoint: Feminist strategies for interviewing and analysis. Social Problems, 37[1], 96-116.

De Wit, J. \& Berner, E. [2009]. Progressive patronage? Municipalities, NGOs, CBOs and the limits to slum dwellers' empowerment. Development and Change, 40(5), 927-947.

Esselaar, S., Stork, C., Ndiwalani, A. \& Deen-Swarray, M. [2008]. ICT usage and its impact on profitability of SMEs in 13 African countries. The MIT Press, 4 [1], 87-100.

Governance Matters (n.d.). Deadwood or just dormant? A guide to stimulating board engagement. Retrieved from http://www.boardcoach.com/downloads/Deadwood-or-Just-Dormant-Board-Leadership-Project-GovernanceMatters.pdf

Granovetter, M. [2005]. The impact of social structure on economic outcomes. Journal of Economic Perspectives, 19(1), [33-50]. Retrieved from http://www.vwl.tuwien.ac.at/hanappi/AgeSo/rp/Granovetter_2005.pdf Granovetter, M. \& Swedberg, R. (Eds.) [1992]. The sociology of economic life. Oxford, England: Westview Press.

Haan, H. C. [1999]. MSE associations and enterprise promotion in Africa. In K. King and S. McGrath (Eds.), Enterprise in Africa. Between poverty and growth [156-168]. London, England: Intermediate Technology Publications.

Harding, S. [1991]. Whose science? Whose knowledge? Thinking from women's lives. Milton Keynes, England: Open University Press.

Hart, K. [1973]. Informal income opportunities and urban employment in Ghana. Journal of Modern African Studies, 11[1], 61-89.

Hirschman, A.0. [1970]. Exit, voice and loyalty. Responses to decline in firms, organizations, and States. Cambridge, Massachusetts, USA: Harvard University Press.

ILO. [2013]. Women and men in the informal economy: A statistical picture. (2nd ed.). Geneva, Switzerland: International Labour Organization.

Kabeer, N. [1999]. Resources, agencies, achievements: Reflections on the measurement of women's empowerment. Development and Change, 30, 435-464.

Kabeer, N. [2008]. Mainstreaming gender in social protection for the informal economy. London, England: Commonwealth Secretariat.

Kenya, Republic of. [2013]. The micro and small enterprises act, No. 55 of 2012. Nairobi, Kenya: National Council for Law Reporting with the Authority of the Attorney-General, 4 January 2013.

Kenya, Republic of. [2013]. Homa Bay County integrated development plan 2013-2017. Homa Bay, Kenya.

Kenya, Republic of. [2016]. Micro, small and medium establishments. Basic report. Nairobi, Kenya: Kenya National Bureau of Statistics.

Kenya, Republic of. [2018]. Economic survey 2018. Nairobi, Kenya: Kenya National Bureau of Statistics.

King, K. [1996]. Jua kali Kenya. Change \& Development in an informal economy 1970-95. London, England: James Currey.

Kinyanjui, M. N. [2010]. Social Relations and Associations in the Informal Sector in Kenya. Social Policy and Development, Programme Paper No. 43. Geneva, Switzerland: United Nations Research Institute for Social Development.

Kinyanjui, M. N. [2011]. Jua kali strategies for socio-economic change in Nairobi. Hemispheres: Studies on Cultures and Societies, [26], 29-46.

Kinyanjui, M. N. [2012]. Vyama, institutions of hope. Ordinary people's market Coordination and society organisation. Ontario, Canada: Nsemia Publishers.

La Pelle, N. [2004]. Simplifying qualitative data analysis using general purpose software tools. Field Methods, 16[1], 85-108.

Liedholm, C. \& Mead, D. [1999]. Small enterprise development. London, England: Routledge.

Lincoln, Y. S. \& Guba, E. G. [1985]. Naturalistic inquiry. Newbury Park, California, USA: SAGE.

Lindell, I. [2010]. Informality and collective organising: Identities, alliances and transnational activism in Africa.

Third World Quarterly, 31[2], 207-222. 
Livingstone, I. [1986]. The 'sponge' effect: Population, employment, and incomes in Kenya." In S. Nigam (Ed.), Jobs and skills programme for Africa. The challenge of employment and basic needs in Africa, [261-269]. Oxford, England: Oxford University Press.

Macharia, K. [2007]. Tensions created by formal and informal use of urban space: The case of Nairobi, Kenya. Journal of Third World Studies, XXIV[2], 145-162.

Maloney, W. [2004]. Informality revisited. World Development, 32[7], 1159-1178.

Maxwell, J.A. [2010]. Using numbers in qualitative research. Qualitative Inquiry, 16[6], 475-482.

May, T. [2001]. Social research. Issues, methods and process (3 $3^{\text {rd }}$ ed.). Buckingham, England: Open University Press.

Mayoux, L. [2001]. Participatory programme learning for women's empowerment in micro-finance programmes: Negotiating complexity, conflict and change. In P. Oakley (Ed.), Evaluating empowerment: Reviewing the Concept and Practice [152-167]. Oxford, England: INTRAC.

McCormick, D. [1987]. Fundis and formality: Very small manufacturers in Nairobi. In M. G. Schatzberg (Ed.), The Political economy of Kenya [161-176]. New York, USA: Praeger Publishers.

McCormick, D., Mitullah, W. V. \& Kinyanjui, M. [2003]. How to collaborate. Associations and other community based organisations among Kenyan micro and small-scale entrepreneurs [IDS Occasional Paper No. 70]. Nairobi, Kenya: University of Nairobi, Institute for Development Studies.

Mead, D. [1999]. MSEs tackle both poverty and growth. In K. King and S. McGrath (Eds.), Enterprise in Africa. Between poverty and growth [61-70]. London, England: Intermediate Technology Publications.

Meagher, K. [2013]. Unlocking the Informal Economy: A Literature Review on Linkages Between Formal and Informal Economies in Developing Countries [WIEGO Working Paper No. 27]. Retrieved from http://www.vumelana.org.za/wp-content/uploads/2014/03/Document-49-Meagher_WIEGO_WP27.pdf.

Miles, M. \& Hubermann, A. [1984]. Qualitative data analysis. London, England: SAGE.

Morse, J. M., Barrett, M., Mayan, M., Olson, K. \& Spiers, J. [2002]. Verification strategies for establishing reliability and validity in qualitative research. International Journal of Qualitative Methods, 1[2], 13-22.

Mutua, J. [2018, October 16]. President Kenyatta 'ashamed' to read his speech. The Daily Nation. Retrieved from https://www.nation.co.ke/news/Uhuru-refuses-to-read-speech-/1056-4808990-1jr9dm/index.html.

Ng'ethe, N. \& Ndua, G. [1984]. The role of the informal sector in the development of small and intermediate-sized cities. A case study of Nakuru [IDS Occasional Paper No. 60]. Nairobi, Kenya: University of Nairobi, Institute for Development Studies.

Olesen, V. [1998]. Feminisms and models of qualitative research. In N. K. Denzin \& Y. S. Lincoln (Eds.) The landscape of qualitative research. Theories and issues [300-332]. London, England: SAGE.

Olson, M. [1965]. The logic of collective action: Public goods and the theory of groups. Cambridge, Massachusetts, USA: Harvard University Press.

Ostrom, E. [2000, Summer]. Collective action and the evaluation of social norms. The Journal of Economic Perspectives, 14[3], 137-158. Retrieved from

http://www.policy.hu/karimli/Ostrom\%20collective\%20action\%20and\%20evolution\%20of\%20social\%20norm s.pdf.

Ostrom, E. [2009]. Governing the commons. The evolution of institutions for collective action. Cambridge, England: Cambridge University Press. Retrieved from http://wtf.tw/ref/ostrom_1990.pdf.

Palmer, R. [2004]. The informal economy in sub-saharan Africa: Unresolved issues of concept, character and measurement [CAS Occasional Paper No. 98]. University of Edinburgh, Centre of African Studies. Retrieved from http://www.cas.ed.ac.uk/research/publications/archive/show paper?result page=76.

Rizzo, M. [2013]. Informalisation and the end of trade unionism as we knew it? Dissenting remarks from a Tanzanian case study. Review of African Political Economy, 40[136], 290-308.

Rogerson, C. M. [2001]. In search of the African miracle: debates on successful small enterprise development in Africa. Habitat International, Volume 25, [115-142].

Rowlands, J. [1997]. Questioning empowerment. Working with women in Honduras. Oxford, England: Oxfam Publications.

Sen, A. [1999]. Development as freedom. New York, USA: Anchor Books. 
Silverman, D. [1999]. Interpreting qualitative data. Methods for analysing talk, text and interaction. Second edition. London, England: SAGE.

Stake, R. [1998]. Case studies. In N. K. Denzin \& Y. S. Lincoln (Eds.). Strategies of Qualitative Inquiry [86-108]. London, England: SAGE.

Stanley, L. \& Wise, S. [1993]. Breaking out again: Feminist ontology and epistemology (2nd ed.). London, England: Routledge.

Stigler, G. J. [1974]. Free riders and collective action: An appendix to theories of economic regulation. The Bell Journal of Economics and Management Science, 5[2], 359-365.

Taylor-Powell, E. \& Renner, M. [2003]. Analyzing qualitative data. University of Wisconsin. Madison, USA: Cooperative Extension Publishing Operations. Retrieved from http://blog.soton.ac.uk/dissertation/files/2013/09/Taylor-Powell-2003.pdf.

Tremblay, C. \& Gutberlet, J. [2012]. Empowerment through participation: assessing the voices of leaders from recycling cooperatives in Sao Paulo, Brazil. Community Development Journal, 47[2], 282-302. Retrieved from http://www.juttagutberlet.com/wp-content/uploads/2013/10/2010-CDI-Empowerment-TremblayGutberlet1.pdf.

Webb, J. W, Bruto, G. D., Tihanyi, L. \& Ireland, R. D. [2012]. Research on entrepreneurship in the informal economy: Framing a research agenda. Journal of Business Venturing. Retrieved from https://pdfs.semanticscholar.org/346f/5d61361d129c370c1e99c99288f0068eb29d.pdf.

Willis, B. [2014]. The advantages and limits of single case study analysis. Retrieved from http://www.eir.info/2014/07/05/the-advantages-and-limitations-of-single-case-study-analysis/.

WSACCO. (2009). By-laws of WSACCO. Homa Bay, Kenya: Homa Bay Women Entrepreneurs Savings and Credit Cooperative Society.

WSACCO. (2012). Annual Progress Report, January 2011- February 2012. Homa Bay, Kenya: Homa Bay Women Entrepreneurs Savings and Credit Cooperative Society.

Yang, W., Liu, W., Viña, A., Tuanmu, M. N., He, G., Dietz, T. \& Liu, J. (2013, July). Nonlinear effects of group size on collective action and resource outcomes. Proceedings of the National Academy of Sciences of the USA.110(27), 10916-10921. Retrieved from http://www.pnas.org/content/110/27/10916.full.pdf

Yazan, B. [2015]. Three approaches to case study methods in education: Yin, Merriam, and Stake. The Qualitative Report. 20[2], 134-152. Retrieved from http://nsuworks.nova.edu/cgi/viewcontent.cgi?article=2102\&context=tqr.

Yin, R. K. [2009]. Case study research: Design and methods. London, England: SAGE.

http://www.kie.co.ke

http://www.wiego.org/informal-economy/about-informal-economy 